\title{
THE CONCEPT OF "MIRACLE IN A FIERY FURNACE" IN BYZANTIUM AND ITS LATER REMINISCENCES
}

\author{
Alexandr A. Romensky \\ State Museum-Preserve “Tauric Chersonesos”, Sevastopol, Russian Federation
}

\begin{abstract}
Introduction. The article discusses the motive of a "miracle in a fiery furnace", based on the story of the Three Holy Children in the Book of Daniel. Methods. The study provides a comparative analysis of the Biblical topos about the trial by fire in Byzantine, Western European and Eastern sources. A semiotic approach of textual study is used. Analysis. In Byzantine hagiography and hymnography, the plot of the "Three Holy Children" was interpreted as a prototype of the Incarnation, so, the sacred situation was reproduced in new historical conditions. In the Lives of Bishops of Cherson, the plot about miracle in the furnace is used for construction the local sacred history. Similar motives are found in the narratives about the baptism of Rus, such as Vita Basilii (the fifth book of Theophanes Continuatus), Vita beati Romualdi by Petrus Damiani, Historia de predicatione episcopi Brunonis. In narrative about conversion of Özbeg Khan to Islam, literary plot was connected with shamanistic representations about the holy fire. Results. The Biblical topos of the "fiery furnace" underwent a semantic transformation within the framework of various discourses. It was used in Byzantine texts for constructing the Christian Identity, while was enhanced by Turkic mythology in Muslim tradition.

Key words: Book of Daniel, Three Holy Children in the Fiery Furnace, Byzantine Hagiography, Byzantine Hymnography, the Baptism of Rus, the Conversion of Özbeg to Islam.

Citation. Romensky A.A. The Concept of "Miracle in a Fiery Furnace" in Byzantium and Its Later Reminiscences. Vestnik Volgogradskogo gosudarstvennogo universiteta. Seriya 4. Istoriya. Regionovedenie. Mezhdunarodnye otnosheniya [Science Journal of Volgograd State University. History. Area Studies. International Relations], 2021, vol. 26, no. 6, pp. 318-330. (in Russian). DOI: https://doi.org/10.15688/jvolsu4.2021.6.23
\end{abstract}

УДК $94+23 / 28$

Дата поступления статьи: 13.05.2021

ББК $63.3(0) 4$

Дата принятия статьи: 21.06.2021

\section{КОНЦЕПТ «ЧУДА В ОГНЕННОЙ ПЕЧИ» В ВИЗАНТИИ И ЕГО ПОЗДНЕЙШИЕ РЕМИНИСЦЕНЦИИ}

\author{
Александр Александрович Роменский \\ Государственный музей-заповедник «Херсонес Таврический», г. Севастополь, Российская Федерация
}

\footnotetext{
Аннотация. В статье рассматривается библейский топос «чуда трех отроков в огненной печи» и его позднейшая трансформация в византийской, западной и восточной традициях. Сюжет о «вавилонских отроках» из Книги пророка Даниила истолковывался в византийской агиографии и гимнографии как прообраз Боговоплощения, с его помощью сакральная ситуация воспроизводилась в новых исторических условиях. Нарратив о чудесном испытании огнем в «Житиях епископов Херсонских» способствовал формированию локальной христианской идентичности в Таврике. Мотив вхождения в огненную печь в византийских и латиноязычных текстах о крещении Руси использовался для конструирования истории христианизации Восточной Европы. Сходная фабула повествования об обращении Узбека в ислам испытала влияние не только литературных стереотипов, но и тенгрианских мифологических представлений.

Ключевые слова: Книга пророка Даниила, «три отрока в пещи огненной», византийская агиография, византийская гимнография, крещение Руси, обращение Узбека в ислам.
} 
Цитирование. Роменский А. А. Концепт «чуда в огненной печи» в Византии и его позднейшие реминисценции // Вестник Волгоградского государственного университета. Серия 4, История. Регионоведение. Международные отношения. - 2021. - Т. 26, № 6. - C. 318-330. - DOI: https://doi.org/10.15688/jvolsu4.2021.6.23

Введение. Представления о сакральности огня и света характерны для целого ряда архаических культур и религиозных систем Евразии, от зороастризма и митраизма до тенгрианства и авраамических монотеистических религий. В большинстве случаев наблюдается важная дихотомия между нетварным небесным светом и светом чувственным, зримым как его отражением [15, с. 37]. Восприятие огня и света как явного проявления трансцедентного, божественного начала обнаруживается во множестве ритуалов и культовых практик. Божественный Огонь как образ-идея выступает элементом конструирования сакральных пространств $[15$, с. $8-10,46]$. В Библии огонь становится одновременно орудием Бога, «служителем Господа» и маркером Божественного присутствия, благодатным образом уничтожения греха и карающим оружием [15, с. 46-48]. Символика огня как священного атрибута особенно прослеживается в псевдоэпиграфической апокалиптической литературе вавилонской иудейской диаспоры, в частности Книге пророка Даниила. Несмотря на то что образ «трех вавилонских отроков» неоднократно исследовался в библеистике и патристике в контексте изучения отдельных памятников, проведение сопоставительного анализа отражения этого библейского сюжета в различных культурах все еще остается актуальным. Представляется целесообразным кратко остановиться на развитии фабулы чудесного испытания огнем в позднейших восточнохристианской, западной и исламской письменных традициях.

Методы. В исследовании проводится сравнительный анализ библейского топоса об испытании огнем в византийских, западноевропейских и восточных источниках. Рассматриваются памятники византийской агиографии и гимнографии, хронистики, латиноязычной агиографии, тюркской чагатайской исторической литературы. В качестве вспомогательных используются методы археологии (интерпретация христианских культовых сооружений) и этнографии (описание ритуальных практик). Изучение сакральных пространств как цело- стного комплекса базируется на концепции иеротопии, изложенной А.М. Лидовым [26, c. 9-32]. Необходимой предпосылкой для работы с нарративными памятниками является применение семиотического подхода к исследованию исторических и культурных феноменов $[28$, с. $6 ; 37$, с. $9-11]$.

Анализ. В видениях пророка Даниила престол «Ветхого денми» ассоциировался с «пламенем огня», перед Ним проходит огненная река, в огонь же повергнуто сокрушенное тело зверя (Дан. 7:9-10). Огонь прежде всего фигурирует в символических контекстах, связанных с очищением и наказанием. Показательно, что он не опаляет трех друзей Даниила, брошенных в раскаленную печь за отказ от поклонения золотому истукану, и в то же время сжигает нечестивых исполнителей казни. Связанные отроки «ходили посреди пламени... благословляя Господа», спасенные ангелом, который сошел в печь и выбросил пламя оттуда, сотворив «шумящий влажный ветер». Пораженный этим чудом Навуходоносор благословляет Бога Седраха, Мисаха и Авденаго (вавилонские имена иудейских юношей Анании, Мисаила и Азарии) и под страхом смерти запрещает произносить на него хулу, «ибо нет иного Бога, который мог бы так спасать» (Дан. 3:19-96). Огонь не опаляет праведников; согласно Книге Маккавеев, «Анания, Азария, Мисаил верою спаслись от пламени» (1 Мак. 2:59). Чудо превращения пламени в росу как следствие верности отроков Господу подчеркивается в молитве Елеазара (3 Мак. 6:5).

Библейская семантика огня неизменно связана с идеей воздаяния за грехи: огонь испепеляет нечестивцев Содома и Гоморры, он же ожидает грешников на грядущем Суде [15, c. 50-52]. При этом огонь является отражением Божественного Света; иерусалимский благодатный огонь, который возжигается, согласно представлению верующих, в Великую субботу, связан с символикой воскресения [38; 27, с. 279-280]. Мотив карающего огня, не раз встречающийся в Ветхом Завете, отразился в сообщении о Седекии и Ахаве, «которых царь 


\section{ВИЗАНТИЙСКОЕ ПРАВОСЛАВИЕ}

вавилонский изжарил на огне» (Иер. 29:22). Другой библейский персонаж - иудейский царь Манассия, выступающий олицетворением нечестия, «провел через огонь» своего сына в ходе языческого ритуала. Позднейшие иудейские комментаторы сообщили неизвестные подробности казни, заставляя Манассию претерпевать страдания на огне внутри медного изваяния: царь безуспешно обращается ко всем языческим божествам, которым поклонялся, и в итоге вспоминает о Боге своих отцов [40, с. 87-88]. В дальнейшем тема мучений и покаяния Манассии, который, согласно «Апокалипсису Варуха», «обрел жилище в огне», переосмысливается в апокрифах [62, p. 127].

Сюжет о чуде с тремя «вавилонскими отроками» получил дальнейшее развитие в творениях святых отцов. Чудесное спасение отроков воспринималось как прообраз грядущего Боговоплощения, соединяя символику зримого и нетварного огня. Об этом образно повествует Иоанн Дамаскин в ямбическом каноне на Рождество Христово: «Ми́ $\rho \alpha \nu$

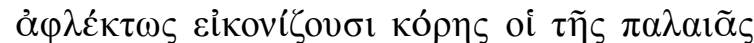

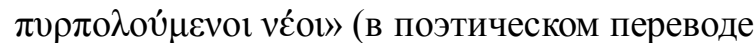
С.С. Аверинцева, «Завета нам предображают Ветхого в среду огня ввергаемые отроки ту Деву, что вместила неопально огнь») [1, с. 185 ; 50, p. 824]. Примечательно, что связь между невещественным огнем и Евхаристией подчеркивается в литургических текстах и комментариях к ним [4, с. 157]. Св. Ефрем Сирин неслучайно называет Тайны Христовы «огнем бессмертным» (используя лексику, которая употреблялась в древности по отношению к языческому священному огню Весты) ( $\pi \tilde{v} \rho$

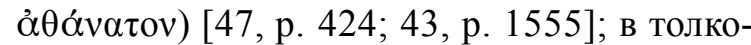
вании на Книгу Даниила сирийский богослов восхищается подвигом трех отроков, ставя в пример их преданность Богу [48, p. 208]. Сохранившиеся лишь в переводе Септуагинты «песнь трех отроков» и «молитва Азарии» заняли важную роль в православной гимнографии и литургике. Чудо спасения из огня, в понимании византийцев, предвещало и грядущее Воскресение Христово, благодаря чему «песнь отроков» с древнейших времен использовалась в службах Великой субботы и праздничной утрени [30, с. 485]. Осмысливая Книгу Даниила, Роман Сладкопевец в своем кон- даке замечает, что «разожженное место сделалось молитвенным и показалось усеянным

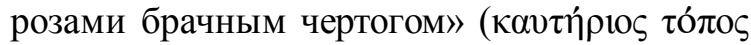

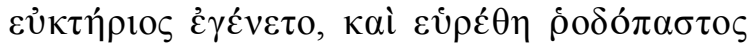
$\pi \alpha ́ \sigma \tau \alpha \varsigma)$, а халдейская печь для отроков стала небесной церковью. Здесь символика огня снова амбивалентна: огненный ангел, сошедший с неба и устрашивший вавилонского царя, показался ему Сыном Божиим; он «показал

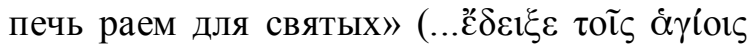

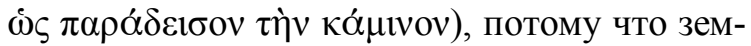
ное пламя преобразилось в присутствии божественного Света [58, p. 390; 44, p. 34]. Согласно Симеону Солунскому, три отрока в пещи изображали и славили Троицу, предвосхищая вочеловечение Логоса [63, col. 639, 640]. Неслучайно образ вавилонских отроков и их чудесное спасение сквозь обращение «пламени в росу» фигурирует в ирмосах покаянного канона к Господу и других молитвословиях $[67, \sigma .326 ; 17$, с. 166-167].

Связь образов Ветхого и Нового Завета сквозь призму сюжета об отроках была драматически выражена в чине пещного действа, совершаемого на Руси по примеру Константинопольской церкви в неделю святых праотцев [11, с. 554-556]. Участники чина - «отроки», облаченные в стихари и венцы, ассоциировались с конкретными ипостасями Троицы, а спасший их ангел в стихах представлялся самим Христом [34, с. 44-45]. Театрализованный диалог «халдеев» с «отроками», лишь внешне опирающийся на сюжетную канву книги Даниила, являл собой образец экзистенциального переживания священной истории, своеобразного воспроизведения священного времени в настоящем. Известно, что впоследствии на Балканах «огненное действо» воссоздавалось не только литургическими средствами, но и как часть реальной обрядовой практики. В связи с этим интересен фиксируемый этнографически в восточной Фракии обряд «нестинарства» (анастенарии) (хождения с иконами и реликвиями по раскаленным углям в день памяти свв. Константина и Елены) [66, p. 58-59]. По фольклорным преданиям, происхождение обычая связано с чудом спасения реликвии Животворящего Креста Господня святым императором Константином Великим, который сошел с небес во время осады турками Константинополя и невреди- 
мым прошел сквозь огонь [15, с. 343-344]. Нельзя исключать влияния ветхозаветного мотива на формирование этого ритуала.

Сюжетные топосы из Книги пророка Даниила неоднократно использовались в византийской агиографии. Мотив чудесного вхождения в огненную печь часто фигурирует в нарративах, повествующих об обращении язычников к вере. Чудо выступает в качестве решающего аргумента, явного доказательства истины проповедуемого учения. Так, ключевым элементом рассказа о епископе Капитоне, сохранившегося в «Житиях св. епископов Херсонесских» и пространном синаксарном «Чуде о св. Капитоне», является вхождение архиерея в разожженную печь и его чудесное спасение, после которого враждебно настроенные язычники изъявляют желание креститься. В большинстве агиографических текстов оппоненты Капитона побуждают его войти в одну из двух печей, разожженных для выделки извести языческого храма [12, с. 24, $31,57-58]$; согласно синаксарному «Чуду», передающему неизвестные по другим версиям «Житий» подробности, сам епископ распорядился устроить в периболе две печи, намереваясь построить храм во имя апостола Петpa $[8$, c. 54]. Пришедшие с утра эллины собираются препятствовать горению печей, тогда Капитон предлагает им провести своеобразное соревнование, определив, кто более могущественный: их идолы или христианский Бог. Для этого он согласился войти в горящую печь, оставив возле печей детей язычников для гарантии исполнения ими оговоренных условий сделки. Помолившись, Капитон дважды осенил печь крестным знаменем, процитировав псалом, использовавшийся в древности при освящении храмов: «Вот врата Господа: правед-

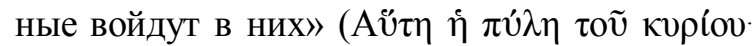

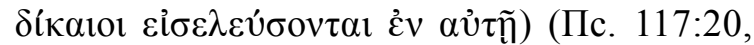
Синодальный перевод). Епископ провел в печи около получаса и вышел оттуда с сияющим и светлым лицом, что окончательно убедило его оппонентов. После оглашения херсонеситы разбирают языческий храм Девы и строят на его месте христианский, в котором и принимают крещение. Днем епископ крестил мужчин и мальчиков, а ночью - девочек и женщин; проведение обряда заняло около двух месяцев [8, с. 54-57].
Впрочем, едва ли епископ опирался лишь на силу убеждения и визуальную демонстрацию Божьего могущества. Тексты «Житий херсонесских епископов» неслучайно сообщают об отряде Феоны с пятьюстами воинов, присланных из Константинополя. Они обеспечивали безопасность Капитона в его пастырских трудах, а впоследствии поселились в восточной части города, «от региона так называемой Малой агоры до места, названного Парфеноном», которая получила наименова-

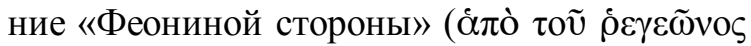

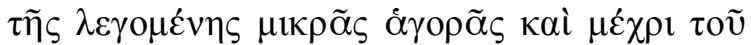

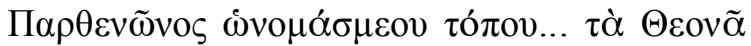

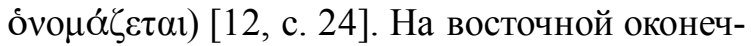
ности Херсонесского мыса в древности располагался священный участок - теменос [13, c. 100], на месте которого была возведена Восточная базилика, вероятно, названная в честь св. апостола Петра $[6$, с. $93 ; 35$, с. $225-$ 226 ; 12, с. 155-157]. По предположению С.Б. Сорочана, отряд «начальствующего» Феоны мог прибыть в город в марте, с началом навигационного сезона. В это время в Херсонесе традиционно проводился посвященный Деве праздник Парфений, к этому событию, вероятно, было приурочено обновление ее храма [12, с. 158-159]. На месте чуда с печью на юго-западе города, как традиционно считается, было возведено четырехапсидное купольное сооружение, вероятно, представлявшее собой «теофанический» меморий. В его центре были обнаружены остатки известеобжигательной печи, которая, по мнению исследователей, могла соотноситься с печью епископа Капитона [9, с. 1588-1590; 23, с. 166-167; 36 , с. $156 ; 12$, с. 160-164]. Разумеется, эта интерпретация, как и датировка памятника, небесспорна [33, с. 207; 12, с. 272-273].

Топографические детали и упоминание о херсонесских «местах памяти» убеждают в местном происхождении агиографического источника. Проблема датировки «Житий» остается дискуссионной. Обычно для разрешения этого вопроса исследователи анализируют контекст исторических реалий, отраженных в тексте, сопоставляя их с немногочисленными памятниками эпиграфики, археологическим материалом и «повествованием о крепости Херсон» в составе трактата «Об управлении империей» $[24$, с. $15-16 ; 7$, с. $155 ; 8$, с. $44-45$; 


\section{ВИЗАНТИЙСКОЕ ПРАВОСЛАВИЕ}

20, с. 246-275]. Как представляется, еще одно косвенное указание на время редактирования «Житий» можно получить, рассматривая их в контексте сложения «Константиновой легенды». Именно к императору Константину Великому, «благочестивому» и «христолюбивому», в большинстве редакций апеллируют христиане, получая от него военную и организационную поддержку [12, с. 24, 31, 45, 48, 57, $95,100]$. Представления об идеальных чертах первого христианского императора, его добродетелях и миссионерских заслугах начали формироваться уже в IV-V вв. [10, с. 186187], но лишь с VII в. и позже его церковное почитание приобрело завершенный характер [65, p. 24-25]; примечательно, что в Патмосской рукописи житий, передающей позднее чтение, венценосец назван «апостольским мужем» [12, с. 31]. Между тем в первоначальной версии текста епископство Капитона, вероятно, хронологически приурочивалось ко времени правления Феодосия Великого; повествование о силовом подавлении сопротивления язычников соответствует исторической действительности конца IV в., а не первой четверти этого столетия [7, с. 5758]. Константин Великий вытесняет Феодосия в позднейших редакциях «Житий», поскольку в восприятии ромеев именно он являлся образцовым христианским правителем [10, с. 166-193].

Мотив огня, карающего и одновременно благодатного, занимает ключевое место в Житии Льва Катанского. В начале повествования агиограф упоминает о вулканическом извержении Этны как очевидном подтверждении существования геенны огненной [2, c. 416-417]. В дальнейшем главный антигерой повествования - нечестивый маг Илиодор - борется с огнем, заставляя его погаснуть во всем Константинополе, и в итоге гибнет на костре, приведенный на место казни святым епископом. Огонь, испепеливший нечестивца, нисколько не опалил ни архиерея, ни даже его облачения, «подобно древнему чуду вавилонских отроков». Примечательно, что угодник Божий «носил горящие угли в поле своего гиматия, кадя и не опаляясь»; таким образом, губительная для грешника огненная стихия в очередной раз подчиняется праведнику [25, с. $25-26 ; 2$, с. 430].
Византийская нарративная традиция о крещении Руси в IX в., по версии «Жизнеописания Василия Македонянина», сообщает о несгоревшем Евангелии, которое иерей бросил в огонь на подтверждение своего рассказа о чуде с тремя отроками. Огонь не повредил книгу, и даже ее застежки оказались целыми, что стало наиболее впечатляющим для варваров, хотя, по-видимому, триумф христианства в этот раз был недолгим, и «неукроти-

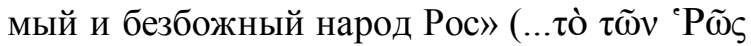

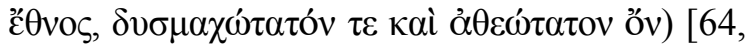
p. 312, 314, 316] вскоре вернулся к прежним культам. Венценосный автор использует популярный агиографический шаблон не только для усиления эффекта повествования, но и в политико-идеологических целях: миссионерские успехи империи времен василевса Михаила III и патриарха Фотия достаются их врагам Василию и Игнатию; основатель Македонской династии - жестокий и прагматичный политик, не чуждавшийся нарушения нравственных норм - представляется ревнителем веры и соработником апостолов $[14$, с. 169 171]. Показательно также и то, что сюжеты из Ветхого Завета охотно использовались в проповедях миссионеров, наряду с рассказами о деяниях Христа. «Житие св. Панкратия Таорминского» свидетельствует, что образная визуализация, как и дидактические наставления с пересказом Священной истории, часто применялись для обращения язычников [61, p. 136,$138 ; 59$, p. 21-23].

Еще одна сходная фабула, связанная с испытанием огнем, содержится в текстах о святом Бруно-Бонифации Кверфуртском и его миссии среди язычников. В «Житии блаженного Ромуальда», написанном Петром Дамиани около 1030 г., святой Бонифаций, проповедуя на Руси, вынужден пройти между двумя подожженными поленницами, чтобы убедить в своей правоте местного короля. Демонстрация чуда происходит после того, как архиепископ в литургических одеяниях со святой водой и кадильницей обходит костер. После триумфа святой крестил «множество язычников» в водах озера [55, p. 58-59]. Тот же сюжет фигурирует в записке Виберта, назвавшего себя одним из капелланов Бруно-Бонифация [29, с. 351-353; 60, S. 70]. Место действия этого агиографического текста - не 
Русь, а Пруссия. Вначале главный герой повествования свергает в огонь идолов, которым поклонялся король-язычник по имени «Нетимер» (Nethimer, вероятное искажение имени князя Владимира, хотя возможны и другие интерпретации [29, с. 374-375]), а затем усаживается на седалище в архиерейском облачении посреди огня. Убежденный с помощью этого эффекта Нетимер «с тремястами мужами» принимает крещение, однако впоследствии и сам архиерей, и его спутники гибнут от рук некоего князя (dux); сохранить жизнь удается лишь ослепленному Виберту, со слов которого, вероятно, и записывалось это известие [60, S. 72]. Историческая достоверность сюжета вызывает сомнения [29, с. 354-355], тем не менее примечательно, что «западноевропейский» взгляд на христианизацию Восточной Европы конструируется с помощью все тех же агиографических стереотипов, что и византийский.

Библейский пророк Даниил почитался не только в иудаизме и христианстве, но и в странах ислама. По мусульманскому преданию, сподвижник пророка Мухаммеда Абу Муса аль-Ашари нашел его каменный саркофаг в городе Сузы. Местные жители использовали гробницу в ритуалах, связанных с вызыванием дождя. Впоследствии пророка перезахоронили на дне русла реки [56, p. 318]. Сходную легенду приводит еврейский путешественник XII в. Вениамин Тудельский. По его словам, в древнем Вавилоне он осматривал руины дворца Навуходоносора и остатки раскаленной печи, а в Сузах персидский царь повелел поместить гроб пророка Даниила в стеклянной раке посередине моста через реку, чтобы предотвратить борьбу за него между обитателями города [19, с. 140-141, 150-152]. Помимо шиитского мавзолея в Сузах, в исламском мире Даниилу были посвящены и другие культовые сооружения, среди которых гробницы в Киркуке и Мосуле, мавзолей в Тарсе, мавзолей «Ходжа Даниер» в Самарканде, возведенный по приказу эмира Тимура [52, p. 85$86 ; 45$, p. 667; 54, p. 112; 53, p. 121]. Имя Даниила (Данияра) фигурировало и в тюркских легендах и преданиях: так, казахские гадателикумалакчи рассказывали, что он использовал гадание с помощью круглых шариков для предсказания судьбы [5, с. 212]. Сюжет о чуде с испытанием проповедника в огненной печи встречается в рассказе историка Шейбанидов Утемиш-хаджи о принятии ислама ханом Узбеком. В этом тексте повествуется о соревновании между «неверными колдунами» и четырьмя мусульманскими святыми [41, c. $250-252 ; 16$, с. $142-144 ; 31$, с. $217-218]$. Колдуны показывали хану трюк со сцеживанием меда в кувшин, который не удался благодаря присутствию мусульман. Полемика сторонников шаманизма и ислама завершилась в двух раскаленных танурах. В один из них был посажен шаман, а в другой мусульманин Баба Туклес, все время молившийся Аллаху и таким образом оставшийся невредимым. Несмотря на то что кольчуга, надетая на его обнаженное тело, накалилась «как пламенеющий уголь докрасна», ни один волос не сгорел на его теле, что и предопределило победу религии Мухаммеда [39, с. 45-46]. Как бы ни трактовали сведения шейбанидского историка, очевидно, что выбор ислама Узбеком предопределялся прежде всего прагматическими мотивами и преследовал цели укрепления власти в ходе политического противоборства в Золотой Орде [49, p. 73-75].

Интерпретируя это известие источника, Д. ДеВиз усматривает в нем отражение обряда, связанного с инициацией шамана, его смертью и последующим воскрешением [46, p. 232-242]. Мифологический контекст сообщения Утемиш-хаджи существенно более широк, в нем, как представляется, литературный топос соединен с реминисценцией неких доисламских обрядов, связанных с почитанием огня. Идея о сакральности огня получила широкое распространение в религиозном мировосприятии и культовой практике кочевых обществ Великой Степи. У тюркских и монгольских народов издревле применялся обряд очищения с прохождением между двух костров. Поклонение огню совершали жених и невеста в день свадьбы. Целый ряд действий по отношению к огню был табуирован: запрещалось лить воду, плевать, шагать через огонь, замахиваться на него оружием [3, c. 22-24; 5, с. 208]. Ч.Ч. Валиханов замечал, что киргизы называют огонь святым (аулие), так же, как и мусульманских праведников [5, c. 208]. Ритуалы с использованием огня применялись при лечении болезней и в шаманс- 


\section{ВИЗАНТИЙСКОЕ ПРАВОСЛАВИЕ}

ких гадательных обрядах. В.П. Костюков сопоставил повествование Утемиш-хаджи с буддийской погребальной обрядностью и практикой жертвенных самосожжений [21, с. 75-78]. Тем не менее нарратив о торжестве ислама над язычниками отразил и некие реалии эпохи: внимание правителей Монгольской империи и улуса Джучи к представителям различных вероучений зафиксировано в аутентичных, независимых друг от друга источниках. Иногда при дворе Чингизидов устраивались полноценные религиозные дебаты с подробным изложением аргументов сторон [51, p. 292; 32, c. 169; 57, p. 37-43]. Целью таких специально организованных споров было не только выяснение религиозной истины, но и сбор актуальной информации о торговых маршрутах, далеких странах и народах [42, с. 288-298]. По свидетельству Марко Поло, хан Хубилай впечатлялся трюками с перемещением чаш, подобно своему родственнику Узбеку. В обращении к римскому понтифику он сетовал на невежество местных христиан, которые проигрывают «колдунам» (буддистам) в визуальной пропаганде [18, с. 281]. Примечательно, что находки чаш с буддийской символикой встречаются на территории бывшего Улуса Джучи [22, с. 29-30; 21, с. 67-68].

Выводы. Библейский топос испытания в «огненной печи» претерпевал семантическую трансформацию в рамках различных дискурсов. Внимание к сюжету в византийской агиографии было предопределено его прообразовательным истолкованием, в котором «вавилонский» огонь соотносился с нетварным, невещественным огнем - одним из сакральных атрибутов, а три иудейских отрока предвосхищали ипостаси Св. Троицы. Мотив «чуда святого Капитона» в Житиях херсонесских епископов, помимо отсылки к ветхозаветному тексту, использовался и для конструирования локальной идентичности: благодаря узнаваемому набору символов, повествование о христианизации Таврики обрело свое место в универсальной истории Церкви. Огонь как карающая и благодатная стихия фигурирует в Житии Льва Катанского. Осмысление ветхозаветного чуда в контексте общей парадигмы развития христианства характерно и для различных версий нарративов о крещении Руси: неизвестный по имени византийский иерей-миссионер и архиепископ Бруно Кверфуртский повторяют подвиг героев Книги пророка Даниила в новых исторических условиях. В среде исламской культуры внимание к визуальному эффекту чудесного усиливалось влиянием тюркской мифологии и ритуальной практикой тенгрианских культов. Демонстрация чуда оставалась эффективным миссионерским средством христианских и мусульманских проповедников спустя много веков после «вавилонского пленения».

\section{СПИСОК ЛИТЕРАТУРЫ}

1. Аверинцев, С. С. Многоценная жемчужина : переводы / С. С. Аверинцев. - Киев : Дух і літеpa, 2004. - 456 c. - (Собрание сочинений).

2. Афиногенов, Д. Е. Пространное житие святителя Льва Катанского / Д. Е. Афиногенов // Scripta Antiqua.-2011.- T. 1.- C. 415-434.

3. Банзаров, Д. Черная вера или шаманство у монголов / Д. Банзаров // Черная вера или шаманство у монголов и другие статьи Доржи Банзарова / под ред. Г. Н. Потанина. - СПб. : Тип. Императ. Акад. наук, 1891. - С. 1-46.

4. Братухин, А. Ю. Образ огня в описании Евхаристии у Климента Александрийского / А. Ю. Братухин // Вестник Пермского университета. Российская и зарубежная филология. - 2013. - Вып. 4 (24). C. $151-158$.

5. Валиханов, Ч. Ч. Тенкри (бог). Собрание сочинений. В 5 т. Т. 1. - Алма-Ата : Гл. ред. Казах. сов. энцикл., 1984. - С. 208-215.

6. Виноградов, А. Ю. Херсонесский храм святого Петра и его эпиграфические памятники / А. Ю. Виноградов // Херсонесский сборник. 2005. - Вып. 14. - С. 91-93.

7. Виноградов, А. Ю. «Миновала уже зима языческого безумия....». Церковь и церкви Херсона в IV в. по данным литературных источников и эпиграфики / А. Ю. Виноградов. - М. : УН-т Дмитрия Пожарского, 2010. - 224 c.

8. Виноградов, А. Ю. Херсонес-Херсон: Две истории одного города. Имена, места и даты в исторической памяти полиса / А. Ю. Виноградов // Вестник древней истории. - 2013. - № 1. - С. 40-58.

9. Гриневич, К. Э. Четырехапсидное здание в Херсонесе (новая попытка его объяснения) / К. Э. Гриневич // Византийский Херсон (вторая половина VI - первая половина X в.). Очерки истории и культуры. В 2 ч. Ч. 2 / С. Б. Сорочан. Харьков : Майдан, 2005. - С. 1586-1591.

10. Дагрон, Ж. Император и священник. Этюд о византийском «цезарепапизме» / Ж. Дагрон ; пер. 
и науч. ред. А. Е. Мусина ; под общ. ред. И. П. Медведева. - СПб. : Филол. фак. СПбГУ : Нестор-история, 2010. $-480 \mathrm{c}$.

11. Дмитриевский, А. А. Чин пещного действа: историко-археологический этюд / А. А. Дмитриевский // Византийский временник. - 1894. - Т. 1. C. $553-600$.

12. Жития епископов Херсонских в контексте истории Херсонеса Таврического / Ю. М. Могаричев [и др.]. - Харьков : Антиква, 2012.-416 с.

13. Золотарев, М. И. Теменос античного Херсонеса. Опыт архитектурной реконструкции / М. И. Золотарев, А. В. Буйских // Вестник древней истории. 1994. -№3. - C. 78-101.

14. Иванов, С. А. Византийское миссионерство: можно ли сделать из «варвара» христианина? / С. А. Иванов. - М. : Яз. слав. культуры, 2003. $-376 \mathrm{c}$.

15. Иеротопия Огня и Света в культуре византийского мира / ред.-сост. А. М. Лидов. - М. : Феория, 2013. $-910 \mathrm{c}$.

16. Исхаков, Д. М. Проблема «окончательной» исламизации Улуса Джучи при хане Узбеке / Д. М. Исхаков // Ислам и власть в Золотой Орде : сб. ст. / под ред. И. М. Миргалеева, Э. Г. Сайфетдиновой. - Казань : Ин-т истории им. Ш. Марджани AH PT, 2012. - C. 129-153.

17. Канонник или Полный молитвослов. СПб. : Домострой, 2001. -553 с.

18. Книга Марко Поло / пер. И. П. Минаева. М. : Гос. изд-во геогр. лит., 1956. -376 с.

19. Книга странствий раби Вениамина / пер. П.В.Марголина // Три еврейских путешественника / под ред. Г. Зеленина. - М. : Гешарим : Мосты культуры, 2004. - С. 65-196.

20. Константин Багрянородный. Об управлении империей. Текст, перевод, комментарий / Константин Багрянородный ; под ред. Г. Г. Литаврина и А. П. Новосельцева. - М. : Наука, 1989. - 496 с.

21. Костюков, В. П. Историзм в легенде об обращении Узбека в ислам / В. П. Костюков // Золотоордынское наследие : материалы Междунар. науч. конф. «Политическая и социально-экономическая история Золотой Орды (XIII-XV вв.)» : сб. ст. Вып. 1 / отв. ред. И. М. Миргалеев. - Казань : Фэн АН РТ, 2009. - C. 67-80.

22. Крамаровский, М. Г. Pax Mongolica и восточное серебро XIII-XIV вв. / М. Г. Крамаровский // Эрмитажные чтения памяти Б. Б. Пиотровского. СПб. : Гос. Эрмитаж, 2000 - С. 29-35.

23. Кутайсов, В. А. Четырехапсидный храм Херсонеса / В. А. Кутайсов // Советская археология. -1982 . - № 1. - С. 155-169.

24. Латышев, В. В. Жития святых епископов Херсонских. Исследование и тексты / В. В. Латышев. - СПб. : Тип. Акад. наук, 1906. - 81 с. - (Запис- ки Императорской академии наук по историко-филологическому отделению ; т. 8, № 3).

25. Латышев, В. В. Неизданные греческие агиографические тексты / В. В. Латышев. - СПб. : Типография Академии наук, 1914. - III, LVI, 152 с. (Записки Императорской академии наук по историко-филологическому отделению ; т. 12, № 2).

26. Лидов, А. М. Иеротопия. Пространственные иконы и образы-парадигмы в византийской культуре / А. М. Лидов. - М. : Дизайн. Информация. Картография, 2009. - 362 с.

27. Лидов, А. М. Святой Огонь. Иеротопические и искусствоведческие аспекты создания «Новых Иерусалимов» / А. М. Лидов // Новые Иерусалимы. Иеротопия и иконография сакральных пространств / ред.-сост. А. М. Лидов. - М. : Индрик, 2009. - C. 277-312.

28. Лотман, Ю. М. Семиосфера / Ю. М. Лотман. - СПб. : Искусство - СПБ, 2010. - 704 с.

29. Назаренко А. В. Древняя Русь на международных путях. Междисциплинарные очерки культурных, торговых, политических связей IX-XII вв. / А. В. Назаренко. - М. : Яз. рус. культуры, 2001.$784 \mathrm{c}$.

30. Никитин, С. И. Вавилонские отроки / С. И. Никитин, А. А. Ткаченко, А. А. Лукашевич // Православная энциклопедия. Т. 6. - М. : Православ. энцикл., 2003. - C. 481-486.

31. Пилипчук, Я. В. Выбор веры в Дешт-иКыпчаке (существовала ли альтернатива исламу?) / Я. В. Пилипчук // Ислам и власть в Золотой Орде : сб. ст. / под ред. И. М. Миргалеева, Э. Г. Сайфетдиновой. - Казань : Ин-т истории им. Ш. Марджани AH PT, 2012. - C. 203-231.

32. Путешествия в восточные страны Плано Карпини и Рубрука / ред. Н. П. Шастиной. - М. : Гос. изд-во геогр. лит., 1957. -272 с.

33. Сазанов, А. В. К вопросу о времени сооружения четырехапсидного храма Херсонеса / А. В. Сазанов // Херсонесский сборник. - 2004. - Вып. 13. C. 202-210.

34. Сазонова, Н. И. Чин пещного действа и интерпретация священной истории в богослужебной практике Русской Православной Церкви XVI-XVII вв. / Н. И. Сазонова // ПРА ЕНМА. Проблемы визуальной семиотики. - 2016. - Вып. 2 (8). - С. 37-52.

35. Сорочан, С. Б. О базилике апостола Петра и храмовом комплексе Восточной площади византийского Херсона / С. Б. Сорочан // Византийский временник. -2006. - Т. 65 (90). - С. 223-230.

36. Сорочан, С. Б. К вопросу о мартириях ранневизантийского Херсона / С. Б. Сорочан // Археологический альманах. - 2012. - № 28. - С. 149-160.

37. Успенский, Б. А. История и семиотика (восприятие времени как семиотическая проблема) / Б. А. Успенский // Избранные труды. В 3 т. Т. 1. 


\section{ВИЗАНТИЙСКОЕ ПРАВОСЛАВИЕ}

Семиотика истории. Семиотика культуры / Б. А. Успенский. - М. : Яз. рус. культуры, 1996. - С. 9-70.

38. Успенский, Н. Д. К истории обряда Святого Огня, совершаемого в Великую Субботу в Иерусалиме / Н. Д. Успенский // Благодатный огонь: миф или реальность? / сост. С. С. Бычков, А. Е. Мусин. М. : Тэтис, 2008. - С. 43-91.

39. Утемиш-хаджи. Кара таварих / транскр. И. М. Миргалеева, Э. Г. Сайфетдиновой, 3. Т. Хафизова; пер. И. М. Миргалеева, Э. Г. Сайфетдиновой, общ. науч. ред. И. М. Миргалеева. - Казань : Ин-т истории им. Ш. Марджани АН РТ, 2017. -312 с.

40. Франко, І. Я. Наливайко в мідянім биці : Причинок до історії легенди / I. Я. Франко // Науковий збірник, присвячений професорові Михайлові Грушевському учениками й прихильниками 3 нагоди його десятилітньої наукової праці в Галичині (1894-1904). - Львів : 3 друкарні Наукового товариства імені Шевченка, 1906. - С. 76-90.

41. Юрченко, А. Г. Хан Узбек: Между империей и исламом (структуры повседневности) : книга-конспект / А. Г. Юрченко. - СПб. : Евразия, 2012. - 400 с.

42. Юрченко, А. Г. Элита Монгольской империи: время праздников, время казней / А. Г. Юрченко. - СПб. : Евразия, 2013. - 432 с.

43. AGreek-English Lexicon/comp. byH. G Liddell and R. Scott ; rev. by H. S. Jones. - Oxford : Clarendon Press, 1996. - XLV, $2041 \mathrm{p}$.

44. Alibertis, D. East Meets East in the Chaldean Furnace: A Comparative Analysis of Romanos's Hymn's and Jacob of Serugh's Homily on the Three Children / D. Alibertis // Journal of the Canadian Society for Syriac Studies. - 2018. - Vol. 18. - P. 24-41.

45. Arimatsu, L. Protecting Cultural Property in Non-International Armed Conflicts : Syria and Iraq / L. Arimatsu, C. Mohbuba // International Law Studies. - 2015. - Vol. 91. - P. 641-698.

46. DeWeese, D. Islamization and Native Religion in Golden Horde: Baba Tükles and Conversion to Islam in Historical and Epic Tradition / D. DeWeese. University Park : Pennsylvania State University Press, 1994. $-655 \mathrm{p}$.

47. Ephraem Syri ad eos, qui Filii Dei naturam ferutantur // Sancti patris nostri Ephraem Syri Opera omnia quae exstant Graece, Syriace, Latine, in sex tomos distributa. T. 3. Graece, et Latine / ed. J. S. Assemani. - Romae : Ex typographia pontificia Vaticana, 1746. - P. 418-424.

48. Ephraem Syri in Danielem Prophetam Explanatio // Sancti patris nostri Ephraem Syri Opera omnia quae exstant Graece, Syriace, Latine, in sex tomos distributa. Series 2. T. 2. Syriace, et Latine / ed. J. S. Assemani. - Romae : Ex typographia pontificia Vaticana, 1740. - P. 203-233.

49. Hautala, R. Comparing the Islamization of the Jochid and Hülegüid Uluses: Muslim and Christian
Perspectives / R. Hautala // Revue des mondes musulmans et de la Méditerranée. - 2018. - Vol. 143. P. 65-80.

50. Ioannes Damascenus. Carmina et cantica // Sancti patris nostri Ioannis Damasceni, monachi et presbyteri Hierosolymitani, opera omnia / accur. J. P. Migne. - Paris : Via dicta d'Amboise, 1860. Col. 818-856. - (Patrologia cursus completus. Series graeca; t. 96).

51. Itinerarium Willelmi de Rubruck / ed. A. van den Wyngaert // Sinica Franciscana. - 1929. - Vol. 1. P. 164-332.

52. Lycklama à Nijeholt, T. M. Voyage en Russie, au Caucase et en Perse, dans la Mésopotamie: Le Kurdistan, la Syrie, la Palestine et la Turquie, exécuté pendant les années 1866, 1867 et 1868. T. 4 / T. M. Lycklama à Nijeholt. - Paris : Arthus Bertrand ; Amsterdam : C. L. Langenhuysen, 1875. - 712 p.

53. Malikov, A. Thought Short Report: The Cult of Saints and Shrines in Samarqand Province of Uzbekistan / A. Malikov // International Journal of Modern Anthropology. - 2010. - Vol. 1, no. 3. P. 116-124.

54. Pancaroğlu, O. Visible / Invisible: Sanctity, History and Topography in Tarsus / O. Pancaroğlu // Akdeniz Kentleri : Gelecek için Geçmişin BirikimiMediterranean Cities : Antiquity as Future [4. Tarih İçinde Mersin Kolokyumu $-4^{\text {th }}$ Mersin in History Colloquium, 2011]. - Mersin : Mersin University Press, 2013. - P. 109-121.

55. Petrus Damiani. Vita beati Romualdi / a cura di G. Tabacco. - Roma : Tipografia del Senato, 1957. 116 p. - (Fonti per la storia d'Italia ; № 94).

56. Rosenmüller, E. F. C. The Biblical Geography of Central Asia. Vol. 1 / E. F. C. Rosenmüller ; transl. from German by R. N. Morren. - Edinburgh : Thomas Clark, 1836. - XVI, 336 p.

57. Rossabi, M. Khubilai Khan. His Life and Times / M. Rossabi. - Berkeley; Los Angeles ; L. : University of California Press, 2009. - XXI, 326 p.

58. Sancti Romani Melodi Cantica. Cantica genuina / ed. P. Maas, C. A. Trypanis. - Oxford : Clarendon Press, 1963. - XXXVI, 546 p.

59. Ševčenko, I. Religious Missions Seen from Byzantium / I. Ševčenko // Harvard Ukrainian Studies. 1988/1989. - Vol. 12/13. - P. 7-27.

60. Sosnowski, M. Anonimowa Passio s. Adalperti martiris (BHL 40) oraz Wiperta Historia de predicatione episcopi Brunonis (BHL 1471b) komentarz, edycja, przekład / M. Sosnowski // Rocznik Biblioteki Narodowej. - 2012. - T. 43. - S. 5-74.

61. Stallman-Pacitti, C. J. The Life of Saint Pankratios of Taormina. Greek Text, English Translation and Commentary / C. J. Stallman-Pacitti ; ed. by J. B. Burke. - Leiden ; Boston : Brill, 2018. - XII, $526 \mathrm{p}$. 
62. Stone, M. E. 4 Ezra and 2 Baruch. Translations, introduction and notes / M. E. Stone, M. Henze. Minneapolis : Fortress Press, 2013. - X, 141 p.

63. Symeon Thessalonicensis archiepiscopus. De sacra precatione // Symeonis Thessalonicensis archiepiscopi opera omnia / accur. J.-P. Migne. - Paris : Via dicta Thibaud, 1866. - Col. 535-668. - (Patrologia cursus completus. Series graeca; t. 155).

64. Theophanis Continuati liber V. Vita Basilii imperatoris / recens. I. Ševčenko. - Berlin ; Boston : De Gruyter, 2011. - XII, 55*, 513 p. - (Corpus fontium historiae byzantinae ; vol. XLII).

65. Thompson, G. L. From Sinner to Saint? Seeking a Consistent Constantine / G. L. Thompson // Rethinking Constantine. History, Theology and Legacy / ed. by E. L. Smither. - Eugene : Pickwick Publications, 2014. - P. 5-25.

66. Xygalatas, D. Ethnography, Historiography, and the Making of History in the Tradition of the Anastenaria / D. Xygalatas // History and Anthropology. - 2011. Vol. 22, no. 1.-P. 57-74.

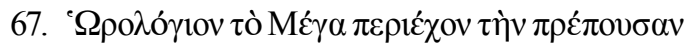

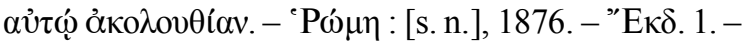
$374 \sigma$.

\section{REFERENCES}

1. Averintsev S.S. Mnogotsennaia zhemchuzhina: perevody [The Valuable Pearl. Translations]. Kyiv, Dukh i litera Publ., 2004. 456 p. (Sobranie sochineniy [Collected Works]).

2. Afinogenov D.E. Prostrannoe zhitie svyatitelya Lva Katanskogo [The Expanded Life of St. Leo, Bishop of Catania]. Scripta Antiqua, 2011, vol. 1, pp. 415-434.

3. Banzarov D. Chernaya vera ili shamanstvo u mongolov [The Black Faith or Shamanism Among the Mongols]. Chernaya vera ili shamanstvo u mongolov i drugie statii Dorzhi Banzarova [The Black Faith or Shamanism Among the Mongols and the Other Papers of Dorzhi Banzarov]. Saint Petersburg, Tipografiya Imperatorskoy akademii nauk, 1891, pp. 1-46.

4. Bratukhin A.Yu. Obraz ognya v opisanii Evkharistii u Klimenta Aleksandriiskogo [The Image of Fire in the Description of the Eucharist by Clement of Alexandria]. Vestnik Permskogo universiteta. Rossiyskaya $i$ zarubezhnaya filologiya [Perm University Herald. Russian and Foreign Philology], 2013, iss. 4 (24), pp. 151-158.

5. Valikhanov Ch.Ch. Tenkri (bog). Sobranie sochineniy. V 5 t. [Tengri (God). Collected Works. In 5 Vols.]. Alma-Ata, Glavnaya redaktsiya Kazakhskoy sovetskoy entsiklopedii, 1984, vol. 1, pp. 208-215.

6. Vinogradov A.Yu. Khersonesskiy khram svyatogo Petra i ego epigraficheskie pamyatniki [Chersonesos' Temple of St. Peter and Its Epigraphic
Monuments]. Khersonesskiy sbornik [Chersonesos Collection], 2005, iss. 14, pp. 91-93.

7. Vinogradov A.Iu. "Minovala uzhe zima yazycheskogo bezumiya...». Tserkov i tserkvi Khersona vIVv. po dannym literaturnykh istochnikov i epigrafiki ["The Winter of Pagan Madness Has Already Passed...". Church and Churches of Cherson in the $4^{\text {th }} \mathrm{c}$. According to Literary Sources and Epigraphy]. Moscow, Universitet Dmitriya Pozharskogo, 2010. 224 p.

8. Vinogradov A.Yu. Khersones-Kherson: Dve istorii odnogo goroda. Imena, mesta $\mathrm{i}$ daty $\mathrm{V}$ istoricheskoy pamyati polisa [Chersonesos and Cherson: Two Histories of One City. Names, Places and Dates in the Historical Memory of the City]. Vestnik drevney istorii [Journal of Ancient History], 2013, no. 1, pp. 40-58.

9. Grinevich K.E. Chetyrekhapsidnoe zdanie v Khersonese (novaya popytka ego obyasneniya) [FourApse Building in Chersonesos (A New Attempt to Explain It)]. Vizantiyskiy Kherson (vtoraya polovina $V I$ - pervaya polovina $X$ v.). Ocherki istorii i kultury. $V 2 \mathrm{ch}$. [Byzantine Cherson. The $2^{\text {nd }}$ Part of the $6^{\text {th }} \mathrm{c}$. the $1^{\text {st }}$ Half of the $10^{\text {th }} \mathrm{c}$. Essays on History and Culture. In 2 Parts]. Kharkov, Maidan Publ., 2005, part 2, pp. 1586-1591.

10. Dagron G. Imperator i svyashchennik. Etyud o vizantiyskom «tsezarepapizme» [Emperor and Priest. Study of Byzantine "Caesaropapism"]. Saint Petersburg, Filologicheskiy fakultet SPbGU; Nestoristoriya Publ., 2010. 480 p.

11. Dmitrievskiy A.A. Chin peshchnogo deystva: istoriko-arkheologicheskiy etyud [Service of Furnace Action: Historical and Archaeological Sketch]. Vizantiiskii vremennik [Byzantina Chronika], 1894, vol. 1, pp. 553-600.

12. MogarichevYu.M., Sazanov, A.V., Sargsyan T.E., Sorochan S.B., Shaposhnikov A.K. Zhitiya episkopov Khersonskikh $v$ kontekste istorii Khersonesa Tavricheskogo [Lives of the Bishops of Cherson in the Context of the History of Tauric Chersonesos]. Kharkov, Antikva Publ., 2012.416 p.

13. Zolotarev M.I., Buyskikh A.V. Temenos antichnogo Khersonesa. Opyt arkhitekturnoy rekonstruktsii [Temenos of Ancient Chersonesos. Experience of Architectural Reconstruction]. Vestnik drevney istorii [Journal of Ancient History], 1994, no. 3, pp. 78-101.

14. Ivanov S.A. Vizantiyskoe missionerstvo: mozhno li sdelat iz «varvara» khristianina? [Byzantine Missionary Work: Is It Possible to Make a Christian from a "Barbarian"?]. Moscow, Yazyki slavyanskoy kultury Publ., 2003.376 p.

15. Lidov A.M. Ierotopiya Ognya i Sveta $v$ kulture vizantiyskogo mira [Hierotopy of Fire and Light in the Culture of the Byzantine World]. Moscow, Feoriya Publ., 2013.910 p. 


\section{ВИЗАНТИЙСКОЕ ПРАВОСЛАВИЕ}

16. Iskhakov D.M. Problema «okonchatelnoy» islamizatsii Ulusa Dzhuchi pri khane Uzbeke [The Problem of the "Final" Islamization of Ulus Jochi Under Цzbeg Khan]. Mirgaleev I.M., Sayfetdinova, E.G., eds. Islam i vlast v Zolotoy Orde: sb. st. [Islam and Power in the Golden Horde. Collection of Articles]. Kazan, Institut istorii imeni Sh. Mardzhani AN RT, 2012, pp. 129-153.

17. Kanonnik ili Polnyy molitvoslov [Canonical or Complete Prayer Book]. Saint Petersburg, Domostroy Publ., 2001. 553 p.

18. Kniga Marko Polo [Book of Marco Polo]. Moscow, Gosudarstvennoe izdatelstvo geograficheskoy literatury, $1956.376 \mathrm{p}$.

19. Kniga stranstviy rabi Veniamina [The Book of Rabbi Benjamin's Wanderings]. Zelenina G., ed. Tri evreyskikh puteshestvennika [Three Jewish Travelers]. Moscow, Gesharim Publ; Mosty kultury Publ., 2004, pp. 65-196.

20. Litavrin G.G., Novoseltsev A.P., eds. Konstantin Bagryanorodnyy. Ob upravlenii imperiey. Tekst, perevod, kommentarij [Constantine Porphyrogenitus. De administrando imperio. Text, Translation and Commentary]. Moscow, Nauka Publ., 1989.496 p.

21. Kostyukov V.P. Istorizm v legende ob obrashcheniy Uzbeka $\mathrm{v}$ islam [Historicism in the Legend of Özbeg Conversion to Islam]. Mirgaleev I.P., ed. Zolotoordynskoe nasledie: materialy Mezhdunar. nauch. konf. "Politicheskaya $i$ sotsialnoekonomicheskaya istoriya Zolotoy Ordy (XIII$X V v v$.)»: sb. st. [Golden Horde Heritage. Proceedings of the International Scientific Conference "Political and Socio-Economic History of the Golden Horde ( $13^{\text {th }}$ $15^{\text {th }}$ Centuries). Collection of Articles]. Kazan, Fen AN RT, 2009, iss. 1, pp. 67-80.

22. Kramarovskiy M.G. Pax Mongolica i vostochnoe serebro XIII-XIV vv. [Pax Mongolica and Eastern Silver of the $13^{\text {th }}-14^{\text {th }}$ Centuries]. Ermitazhnye chteniya pamyati B.B. Piotrovskogo [Hermitage Readings in Memory of B.B. Piotrovsky]. Saint Petersburg, Gosudarstvenniy Ermitazh, 2000, pp. 29-35.

23. Kutaysov V.A. Chetyrekhapsidnyy khram Khersonesa [The Four-Apse Temple of Chersonesos]. Sovetskaya arkheologiya [Soviet Archaeology], 1982, no. 1, pp. 155-169.

24. Latyshev V.V. Zhitiya svyatykh episkopov Khersonskikh. Issledovanie i teksty [Lives of the Holy Bishops of Cherson. Research and Texts]. Saint Petersburg, Tipografiya Akademii nauk, 1906. 81 p. (Zapiski Imperatorskoy akademii nauk po istorikofilologicheskomu otdeleniyu [Notes of the Imperial Academy of Sciences for the Department of History and Philology]; vol. 8, no. 3).

25. Latyshev V.V. Neizdannye grecheskie agiograficheskie teksty [Unpublished Greek
Hagiographic Texts]. Saint Petersburg, Tipografiya Akademii nauk, 1914. III, LVI, 152 p. (Zapiski Imperatorskoy akademii nauk po istorikofilologicheskomu otdeleniyu [Notes of the Imperial Academy of Sciences for the Department of History and Philology]; vol. 12, no. 2).

26. Lidov A.M. Ierotopiya. Prostranstvennye ikony $i$ obrazy-paradigmy $v$ vizantiyskoy kulture [Hierotopy. Spatial Icons and Images-Paradigms in Byzantine Culture]. Moscow, Dizayn. Informatsiya. Kartografiya Publ., 2009. 362 p.

27. Lidov A.M. Svyatoy Ogon. Ierotopicheskie i iskusstvovedcheskie aspekty sozdaniya «Novykh Ierusalimov» [The Holy Fire. Hierotopical and Art Historical Aspects of the Creation of "New Jerusalems"]. Lidov A.M., ed. Novye Ierusalimy. Ierotopiya $i$ ikonografiya sakralnykh prostranstv [New Jerusalems. Hierotopy and Iconography of Sacred Spaces]. Moscow, Indrik Publ., 2009, pp. 277-312.

28. Lotman Yu.M. Semiosfera [Semiosphere]. Saint Petersburg, Iskusstvo - SPB Publ., 2010. 704 p.

29. Nazarenko A.V. Drevnyaya Rus na mezhdunarodnykh putyakh. Mezhdistsiplinarnye ocherki kulturnykh, torgovykh, politicheskikh svyazey IX-XII vv. [Ancient Rus' on International Routes. Interdisciplinary Sketches of Cultural, Trade, Political Ties of the $9^{\text {th }}-12^{\text {th }}$ Centuries]. Moscow, Yazyki russkoy kultury Publ., 2001. 784 p.

30. Nikitin S.I., Tkachenko A.A., Lukashevich A.A. Vavilonskie otroki [Babylonian Children]. Pravoslavnaya entsiklopediya [Orthodox Encyclopaedia]. Moscow, Pravoslavnaya entsiklopediya Publ., 2003, vol. 6. pp. 481-486.

31. Pilipchuk Ya.V. Vybor very v Desht-i-Kypchake (sushchestvovala li alternativa islamu?) [Choice of Faith in Desht-i-Kypchak (Was There an Alternative to Islam?)]. Mirgaleev I.P., Sayfetdinova E.G., eds. Islam $i$ vlast v Zolotoy Orde: sb. st. [Islam and Power in the Golden Horde. Collection of Articles]. Kazan, Institut istorii imeni Sh. Mardzhani AN RT, 2012, pp. 203-231.

32. Shastina N.P., ed. Puteshestviya v vostochnye strany Plano Karpini i Rubruka [Travels to the Eastern Countries of Plano Carpini and Rubruck]. Moscow, Gosudarstvennoe izdatelstvo geograficheskoy literatury, 1957.272 p.

33. Sazanov A.V. K voprosu o vremeni sooruzheniya chetyrekhapsidnogo khrama Khersonesa [On the Question of the Time of Construction of the Four-Apse Temple of Chersonesos]. Khersonesskiy sbornik [Chersonesos Collection], 2004, iss. 13, pp. 202-210.

34. Sazonova N.I. Chin peshchnogo deystva i interpretatsiya svyashchennoy istorii $\mathrm{V}$ bogosluzhebnoy praktike Russkoy Pravoslavnoy Tserkvi XVI-XVII vv. [Service of Furnace Performance and Interpretation of Sacred History in the Liturgical 
Practice of the Russian Orthodox Church of the $16^{\text {th }}$ $17^{\text {th }}$ Centuries]. PRAKSEMMA. Problemy vizualnoy semiotiki [PRAXEMA. Journal of Visual Semiotics], 2016, iss. 2 (8), pp. 37-52.

35. Sorochan S.B. O bazilike apostola Petra i khramovom komplekse Vostochnoy ploshchadi vizantiyskogo Khersona [On the Basilica of the Apostle Peter and the Temple Complex of the Eastern Square of Byzantine Cherson]. Vizantiiskii vremennik [Byzantina Chronika], 2006, vol. 65 (90), pp. 223-230.

36. Sorochan S.B. K voprosu o martiriiakh rannevizantiiskogo Khersona [On the Question of the Martyria of Early Byzantine Cherson]. Arkheologicheskiy almanakh [Archaeological Almanac], 2012, no. 28, pp. 149-160.

37. Uspenskiy B.A. Istoriya i semiotika (vospriyatie vremeni kak semioticheskaya problema) [History and Semiotics. Perception of Time As a Semiotic Problem]. Uspenskiy B.A. Izbrannye trudy. V $3 t$. T. 1. Semiotika istorii. Semiotika kultury [Selected Works. In 3 Vols. Vol. 1. Semiotics of History. Semiotics of Culture]. Moscow, Yazyki russkoy kultury Publ., 1996, pp. 9-70.

38. Uspenskiy N.D. K istorii obryada Svyatogo Ognya, sovershaemogo v Velikuyu Subbotu v Ierusalime [On the History of the Rite of the HolyFire, Performed on Holy Saturday in Jerusalem]. Bychkov S.S., Musin A.E., eds. Blagodatnyy ogon: mif ili realnost? [The Holy Fire: Myth or Reality?]. Moscow, Tetis Publ., 2008, pp. 43-91.

39. Mirgaleev I.M., ed. Utemish-khadzhi. Kara tavarikh [Utemish-haji. Kara tavarikh]. Kazan, Institut istorii imeni Sh. Mardzhani AN RT, 2017.312 p.

40. Franko I.Ya. Nalyvaiko v midianim bytsi: Prychynok do istorii legendy [Nalyvaiko in the Copper Ox: To the History of the Legend]. Naukovyi zbirnyk, prisviachenyi profesorovi Mykhailovi Grushevskomu uchenykami i prykhylnykamy z nagody iogo desiatylitnioi naukovoi pratsi v Galychyni (18941904) [Festschrift, Dedicated to Professor M. Grushevsky on the $10^{\text {th }}$ Anniversary of His Scientific Work in Galychyna (1894-1904)]. Lviv, Z drukarni Naukovogo tovaristva imeni Shevchenka, 1906, pp. 76-90.

41. Yurchenko A.G. Khan Uzbek: Mezhdu imperiey $i$ islamom (struktury povsednevnosti): kniga-konspekt [Khan Özbeg: Between Empire and Islam (Structures of Everyday Life). Survey Book]. Saint Petersburg, Evraziya Publ., 2012. 400 p.

42. Yurchenko A.G. Elita Mongolskoy imperii: vremya prazdnikov, vremya kazney [Elite of the Mongol Empire: Time of Holidays, Time of Executions]. Saint Petersburg, Evraziya Publ., 2013. 432 p.

43. Liddell H.G., Scott R., Jones H.S., eds. A Greek-English Lexicon. Oxford, Clarendon Press, 1996. XLV, $2041 \mathrm{p}$.

44. Alibertis D. East Meets East in the Chaldean Furnace: A Comparative Analysis of Romanos's
Hymn's and Jacob of Serugh's Homily on the Three Children. Journal of the Canadian Society for Syriac Studies, 2018, vol. 18, pp. 24-41.

45. Arimatsu L., Mohbuba C. Protecting Cultural Property in Non-International Armed Conflicts: Syria and Iraq. International Law Studies, 2015, vol. 91, pp. 641-698.

46. DeWeese D. Islamization and Native Religion in Golden Horde: Baba Tükles and Conversion to Islam in Historical and Epic Tradition. University Park, Pennsylvania State University Press, 1994. 655 p.

47. Ephraem Syri ad eos, qui Filii Dei naturam ferutantur. Assemani J.S., ed. Sancti patris nostri Ephraem Syri Opera omnia quae exstant Graece, Syriace, Latine, in sex tomos distributa. T. 3. Graece, et Latine. Rome, Ex typographia pontificia Vaticana, 1746, pp. 418-424.

48. Ephraem Syri in Danielem Prophetam Explanatio. Assemani J.S., ed. Sancti patris nostri Ephraem Syri Opera omnia quae exstant Graece, Syriace, Latine, in sex tomos distributa. Series 2. T. 2. Syriace et Latine. Rome, Ex typographia pontificia Vaticana, 1740, pp. 203-233.

49. Hautala R. Comparing the Islamization of the Jochid and Hülegüid Uluses: Muslim and Christian Perspectives. Revue des mondes musulmans et de la Méditerranée, 2018, vol. 143, pp. 65-80.

50. Ioannes Damascenus. Carmina et cantica. Migne J.-P., ed. Sancti patris nostri Ioannis Damasceni, monachi et presbyteri Hierosolymitani, opera omnia. Paris, Via dicta d'Amboise, 1860, cols. 818-856. (Patrologia cursus completus. Series graeca; t. 96).

51. WyngaertA. van den, ed. Itinerarium Willelmi de Rubruck. Sinica Franciscana, 1929, vol. 1, pp. 164-332.

52. Lycklama à Nijeholt T.M. Voyage en Russie, au Caucase et en Perse, dans la Mésopotamie: le Kurdistan, la Syrie, la Palestine et la Turquie, exécuté pendant les années 1866, 1867 et 1868. T. 4. Paris, Arthus Bertrand, Amsterdam, C.L. Langenhuysen, 1875.712 p.

53. Malikov A. Thought Short Report: The Cult of Saints and Shrines in Samarqand Province of Uzbekistan. International Journal of Modern Anthropology, 2010, vol. 1, no. 3, pp. 116-124.

54. Pancaroğlu O. Visible / Invisible: Sanctity, History and Topography in Tarsus. Akdeniz Kentleri: Gelecek için Geçmişin Birikimi - Mediterranean Cities: Antiquity As Future (4. Tarih İçinde Mersin Kolokyumu - $4^{\text {th }}$ Mersin in History Colloquium, 2011). Mersin, Mersin University Press, 2013, pp. 109-121.

55. Tabacco G., ed. Petrus Damiani. Vita beati Romualdi. Rome, Tipografia del Senato, 1957. 116 p. (Fonti per la storia d'Italia; no. 94).

56. Rosenmüller E.F.C. The Biblical Geography of Central Asia. Edinburgh, Thomas Clark, 1836, vol. 1. $\mathrm{XVI}, 336 \mathrm{p}$. 


\section{ВИЗАНТИЙСКОЕ ПРАВОСЛАВИЕ}

57. Rossabi M. Khubilai Khan. His Life and Times. Berkeley, Los Angeles, London, University of California Press, 2009. XXI, 326 p.

58. Maas P., Trypanis C.A., eds. Sancti Romani Melodi Cantica. Cantica genuina. Oxford, Clarendon Press, 1963. XXXVI, 546 p.

59. Ševčenko I. Religious Missions Seen from Byzantium. Harvard Ukrainian Studies, 1988/1989, vols. 12/13, pp. 7-27.

60. Sosnowski M. Anonimowa Passio s. Adalperti martiris (BHL 40) oraz Wiperta Historia de predicatione episcopi Brunonis (BHL 1471b) komentarz, edycja, przekład. Rocznik Biblioteki Narodowej, 2012, vol. 43, pp. 5-74.

61. Stallman-Pacitti C.J., Burke J.B., ed. The Life of Saint Pankratios of Taormina. Greek Text, English Translation and Commentary. Leiden, Boston, Brill, 2018. XII, $526 \mathrm{p}$.

62. Stone M.E., Henze M. 4 Ezra and 2 Baruch. Translations, Introduction and Notes. Minneapolis, Fortress Press, 2013. X, 141 p.
63. Symeon Thessalonicensis archiepiscopus. De sacra precatione. Migne J.-P., ed. Symeonis Thessalonicensis archiepiscopi opera omnia. Paris, Via dicta Thibaud, 1866, cols. 535-668. (Patrologia cursus completus. Series graeca; t. 155).

64. Ševčenko I., ed. Theophanis Continuati liber V. Vita Basilii imperatoris. Berlin, Boston, De Gruyter, 2011. XII, 55*, 513 p. (Corpus fontium historiae byzantinae; vol. 42).

65. Thompson G.L. From Sinner to Saint? Seeking a Consistent Constantine. Smither E.L., ed. Rethinking Constantine. History, Theology and Legacy. Eugene, Pickwick Publications, 2014, pp. 5-25.

66. Xygalatas D. Ethnography, Historiography, and the Making of History in the Tradition of the Anastenaria. History and Anthropology, 2011, vol. 22, no. 1, pp. 57-74.

67. Ōrologion to Mega periechon tēn prepousan autō akolouthian [The Great Horologion that Embraces Its Inherent Sequence]. Rome, s.n., 1876, $1^{\text {st }}$ ed. 374 p.

\section{Information About the Author}

Alexandr A. Romensky, Candidate of Sciences (History), Researcher, Department of Byzantine History, State Museum-Preserve "Tauric Chersonesos", Drevnyaya St, 1, 299045 Sevastopol, Russian Federation, alexandrosromensky@gmail.com, https://orcid.org/0000-0003-0936-3740

\section{Информация об авторе}

Александр Александрович Роменский, кандидат исторических наук, научный сотрудник отдела византийской истории, Государственный музей-заповедник «Херсонес Таврический», ул. Древняя, 1, 299045 г. Севастополь, Российская Федерация, alexandrosromensky@gmail.com, https://orcid.org/0000-0003-0936-3740 